DOE/RL-91-31

Revision 4

\title{
Hanford Site Waste Minimization and Pollution Prevention Awareness Program Plan
}

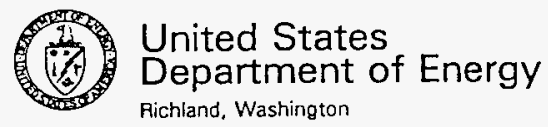

Richland, Washington

Approved for Public Release 
TRADEMARK DISCLANMER

Reforence herein to any specific commercial product, process, or sarvice by trade name, tredemark, manufecturer, or otherwiso, does not necessarily constitute or imply its ondorsement, recommondation, or favoring by the United States Government or any agency thereof or its contractors or subcontractors.

This report has been teproduced from the best available copy. Available in paper copy and microfiche.

Available to the U.S. Department of Energy

and its contractors from

U.S. Department of Energy

Office of Sciantific and Technical Information (OSTI)

P.O. Box 62

Oek Ridge, TN 37831

(515) $576-8401$

Available to the public from the U.S. Department of Commerce National Tochnical Information Service (NTIS)

5285 Port Royal Rood

Springfield, VA 22161

तO3) $487-4650$

Printed in the United Stute, of Americe

DISCLM-5.CHP (8-95) 
DOE/RL-91-31

Revision 4

UC-721

\section{Hanford Site Waste Minimization and Pollution Prevention Awareness Program Plan}

Date Published

September 1998

United States

Department of Energy

P.O. Box 550

Pichland, Washington 99352 
Prepared By:

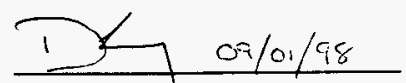

D. E. McKenney, Manager

Strategic Planning

Waste (Management Federal Services of Hanford, Inc

Accepted By:

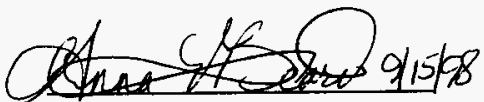

A. V. Beard, Program Manager

Waste Minimization

Waste Programs Division

U. S. Department of Energy

Richland Operations Office, $R \mathbf{L}$

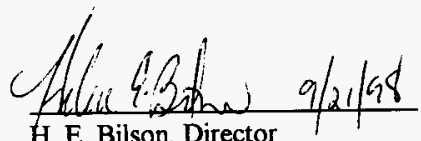

H. E. Bilson, Director

Waste Programs Division

U. S. Department of Energy

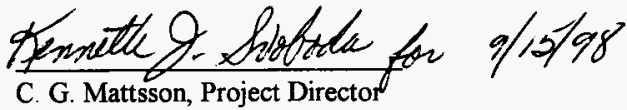

Waste Management

Fluor Daniel Hanford, Inc.
Ezyberena 9.11-98

E. M. Bowers, Team Leader Environmental Site Support Waste Programs Division

U. S. Department of Energy Richland Operations Office, RL

C. A. Hansen

Assistant Manager for Waste Management

U. S. Department of Energy 


\begin{abstract}
This plan, which is required by U. S. Department of Energy (DOE) Order 5400.1, provides waste minimization and pollution prevention guidance for all Hanford Site contractors. The plan is primary in a hierarchical series that includes the Hanford Site Waste Minimization and Pollution Prevention Awareness Program Plan, Prime contractor implementation plans, and the Hanford Site Guide for Preparing and Maintaining Generator Group Pollution Prevention Program Documentation (DOE-RI, 1997a) describing programs required by Resource Conservation and Recovery Act of 1976 (RCRA) 3002(b) and 3005(h) (RCRA and EPA, 1994). Items discussed include the pollution prevention policy and regulatory background, organizational structure, the major objectives and goals of Hanford Site's pollution prevention program, and an itemized description of the Hanford Site pollution prevention program. The document also includes U.S. Department of Energy, Richland Operations Office's (RL's) statement of policy on pollution prevention as well as a listing of regulatory drivers that require a pollution prevention program.
\end{abstract}


DOE/RL-91-31, Rev. 4

This page intentionally left blank. 


\section{CONTENTS}

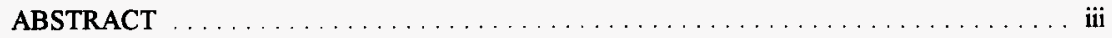

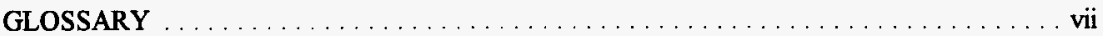

ABBREVIATIONS AND ACRONYMS $\ldots \ldots \ldots \ldots \ldots \ldots \ldots \ldots \ldots \ldots$ vii

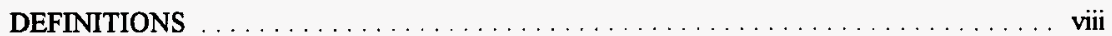

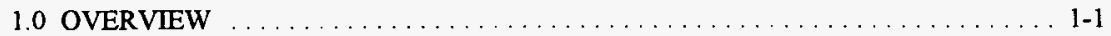

2.0 POLICY AND REGULATORY BACKGROUND . . . . . . . . . . . . . 2-1

2.1 U.S. Department of Energy . . . . . . . . . . . . . . . . . . . 2-1

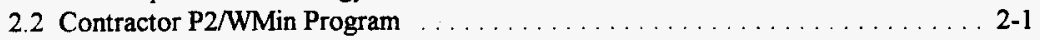

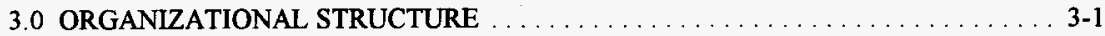

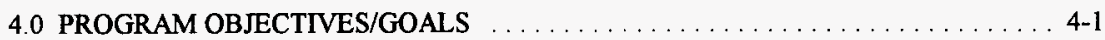

4.1 Objectives to be Immediately Implemented $\ldots \ldots \ldots \ldots \ldots \ldots \ldots \ldots$ 4-1

4.2 Near-Term and Out-Year Objectives . . . . . . . . . . . . . . . . .

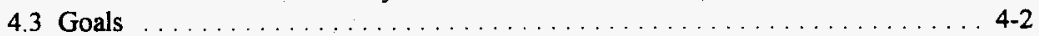

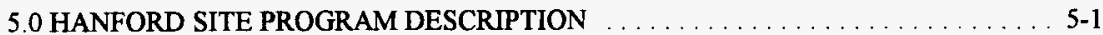

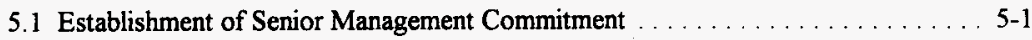

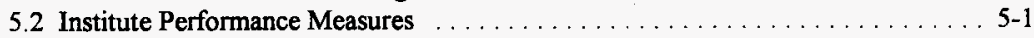

5.3 Perform Waste Minimization Assessments and Implement High

Return-on-Investment P2/WMin Projects . . . . . . . . . . . . . 5-1

5.4 Design Pollution Prevention Into New Products, Processes, and Facilities . . . . 5 5-2

5.5 Develop and Maintain Hanford Site Pollution Prevention Programs that Comply with Federal, State and Departmental Directives . . . . . . . . . . . . . 5-2

5.6 Waste Minimization/Pollution Prevention Techniques . . . . . . . . . . . 5-2

5.6 .1 Inventory Management . . . . . . . . . . . . . . . . . . . . . 5-3

5.6 .2 Maintenance Program . . . . . . . . . . . . . . . . . . . . . . 5-3

5.6 .3 Recycling and Reuse . . . . . . . . . . . . . . . . . . . . .

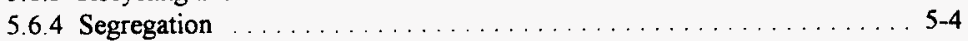

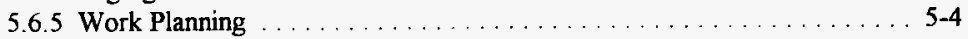

5.7 Pollution Prevention Reporting and Tracking $\ldots \ldots \ldots \ldots \ldots \ldots \ldots .4 .4$

5.7.1 Pollution Prevention Documentation Reporting Systems ......... 5-4

5.7.2 Pollution Prevention Tracking Systems . . . . . . . . . . . . . . 5-4

5.8 Reduce Releases of Toxic Chemicals . . . . . . . . . . . . . . . . . 5-5

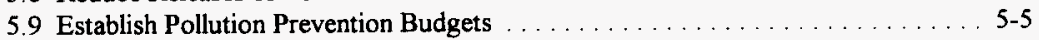

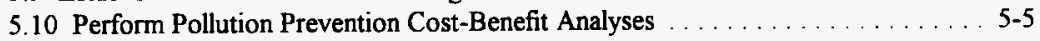

5.11 Facilitate Technology Transfer and Information Exchange . . . . . . . . . 5-6

5.12 Implement Pollution Prevention Awareness Programs . . . . . . . . . . 5 5-6 
5.13 Implement Environmentally Sound Pollution Prevention Procurement Practices

5.14 Integrate Pollution Prevention Into Research, Development, Demonstration, Testing, and Evaluation Programs ............. 5-7

5.15 Assure Consistent Policies, Orders, and Procedures . . . . . . . . . . . . . . . . 5 5-7

5. 16 Implement Pollution Prevention Outreach and Public Involvement . . . . . . . . . 5-8

5.17 Develop Pollution Prevention Incentives Programs ................ . 5-8

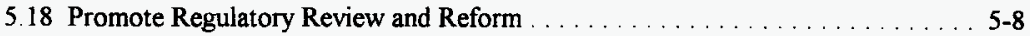

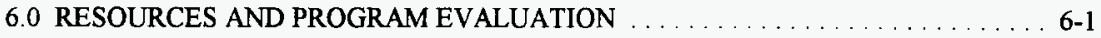

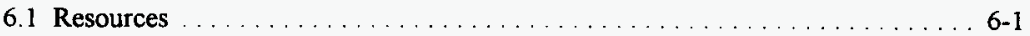

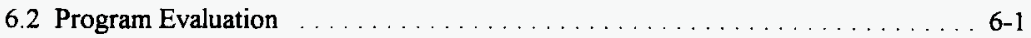

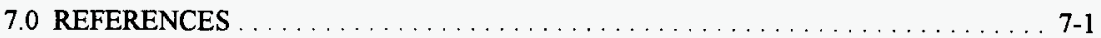

APPENDIXES

A U.S. DEPARTMENT OF ENERGY-RICHLAND OPERATIONS OFFICE POLLUTION PREVENTION POLICY $\ldots \ldots \ldots \ldots \ldots \ldots \ldots \ldots \ldots \ldots$ A-1

B LEGAL AND POLICY BACKGROUND $\ldots \ldots \ldots \ldots \ldots \ldots \ldots \ldots$ B-1

C SECRETARIAL MEMORANDUM: DEPARTMENT POLLUTION PREVENTION GOALS . . . . . . . . . . . . . . . . . . . C $\mathrm{C}-1$

\section{LIST OF FIGURES}

3-1 Hanford Site P2/WMin Program Organizational Chart

LIST OF TABLES

4-1 Hanford Site Goals 


\section{GLOSSARY}

\section{ABBREVIATIONS AND ACRONYMS}

BHI

CAA

CERCLA

CFC

CFR

CWA

DOE

DOE-HQ

DOE-RL

Ecology

EO

EPA

EPCRA

FDH

FFCA

FY

ISMS

LLW

MACT

MLLW

P2

$\mathrm{P} 2 /$ WMin

P2OA

PCB

PNNL

PPA

RCRA

RDDT\&E

RL

ROI

TRU

TSCA

WAC

WMA

WMH

WMin

WPD
Bechtel Hanford, Inc.

Clean Air Act

Comprehensive Environmental Response, Compensation and Liability Act

Chlorofluorocarbon

Code of Federal Regulations

Clean Water Act

U.S. Department of Energy

U.S. Department of Energy-Headquarters

U.S. Department of Energy, Richland Operations Office

Washington State Department of Ecology

Executive Order

U.S. Environmental Protection Agency

Emergency Planning and Community Right-To-Know Act of 1986

Fluor Daniel Hanford, Inc.

Federal Facilities Compliance Act

Fiscal Year

Integrated Environment, Safety and Health Management System

Low-Level Waste

Maximum Achievable Control Technology

Mixed Low-Level Waste

Pollution Prevention

Pollution Prevention/Waste Minimization

Pollution Prevention Opportunity Assessment

Polychlorinated Biphenyl

Pacific Northwest National Laboratory

Pollution Prevention Act

Resource Conservation and Recovery Act of 1976

Research, Development, Demonstration, Testing, and Evaluation

U.S. Department of Energy, Richland Operations Office

Return On Investment

Transuranic Waste

Toxic Substances Control Act of 1976

Washington Administrative Code

Waste Minimization Assessment

Waste Management Federal Services of Hanford, Inc.

Waste Minimization

Waste Programs Division 


\section{DEFINITIONS}

Affirmative Procurement. A program that ensures that items composed of recovered materials will be purchased to the maximum extent practicable, consistent with Federal law and procurement regulations (RCRA, Section 6002 and 40 Code of Federal Regulations (CFR) 247). Guidance on this program has been issued and is updated as the U. S. Environmental Protection Agency (EPA) issues additional guidelines.

Cleanup/Stabilization Waste. Cleanup/stabilization includes environmental restoration of contaminated media (soil, groundwater, surface water, sediments, etc.), stabilization of nuclear and non-nuclear (chemical) materials, and deactivation and decommissioning (including decontamination) of facilities.

Cleanup/stabilization waste consists of one-time operations waste produced from environmental restoration activities, including primary and secondary wastes associated with retrieval and remediation operations, "legacy wastes," and wastes from decontamination and decommissioning/transition operations. It also includes all Toxic Substances Control Act of 1976 (TSCA) regulated wastes, such as polychlorinated biphenyl-contaminated fluids or equipment (TSCA).

Cleanup/stabilization activities that generate wastes do not necessarily occur at a single point in time, but may last for several years while producing wastes. By definition, these activities are not considered to be routine (periodic and/or on-going), because the waste is a direct result of past operations and activities, rather than a current process. Newly generated wastes that are produced during these "one-time operations" are considered a secondary waste stream, and are separately accounted for whenever possible. This secondary (newly generated) waste usually results from common activities such as handling, sampling, treatment, repackaging, shipping, etc.

Generator. Each contractor within the scope of the Pollution Prevention/Waste Minimization (P2/WMin) Program whose activities or processes produce waste.

Generator Group. As defined by the responsible contractor, any discrete activity, project, or facility whose act or process produces waste.

Goal. A specific result toward which efforts are directed.

Hazardous Substance. Any hazardous substance listed as a hazardous substance in the Emergency Planning and Community Right-to-Know Act (EPCRA) and any further updates, and all ozone depleting compounds as defined by the Montreal Protocol of October 1987 and any further updates of the protocol.

Hazardous Waste. Those solid wastes that exhibit any of the characteristics of hazardous waste identified in 40 CFR 261, Subpart C (i.e., ignitable, corrosive, reactive, or toxic), or that are listed in 40 CFR 261, Subpart D, "List of Hazardous Waste." 
Low-Level Waste (LLW). Waste that contains radioactivity and is not classified as high-level waste, transuranic waste (TRU), or spent nuclear fuel, or by-product material as defined by DOE Order 5820.2A (DOE, 1988a). Test specimens of fissionable material that are irradiated for research and development only, and not for the production of power or plutonium, may be classified as LLW, provided the concentration of transuranic is less than 100 nanocuries per gram (nCi/g)

Mixed Low-Level Waste (MLLW). LLW containing hazardous components as defined by the RCRA (also low-level mixed waste).

Mixed Waste. Waste containing both radioactive and hazardous components as defined by the Atomic Energy Act of 1954 and the RCRA, respectively.

Non-Routine Waste. Identical to waste from Cleanup/Stabilization activities.

Pellution Prevention. The use of materials, processes, and practices that reduce or eliminate the generation and release of pollutants, contaminants, hazardous substances, and waste into land, water, and air. For DOE, this includes recycling activities.

Pollution Prevention Opportunity Assessment (P2OA). Evaluation and appraisal of a process, activity, or operation as a way to identify potential waste minimization opportunities.

RCRA-Regulated Waste. Solid waste, not specifically excluded from regulations under 40 CFR 261 4, "Identification and Listing of Hazardous Waste," or delisted by petition, that is either a listed hazardous waste (40 CFR 261.30 to 261.33 ) or exhibits the characteristics of a hazardous waste (40 CFR 261.20 to 261.24 ).

Recycling. Recycling techniques are characterized as use, reuse, and reclamation techniques (resource recovery). Use or reuse involves the return of a potential waste material either to the originating process as a substitute for an input material or to another process as an input material. Reclamation is the processing or regeneration of a material to recover a useable product.

Routine Operations Waste. Normal operations waste produced from any type of production, analytical, and/or research and development laboratory operations; treatment, storage, or disposal operations; "work-for-others;" or any periodic and recurring work that is considered ongoing. The term "normal operations" refers to the type of ongoing process (e.g., production) not the specific activity that produced the waste. Periodic laboratory or facility clean-outs and spill cleanups that occur as a result of these processes are also considered normal operations.

Sanitary Waste. All non-hazardous and non-radioactive waste disposed in a sanitary landfill including demolition waste, industrial wastes, and wastes such as garbage generated by normal housekeeping activities. 
Source Reduction. The elimination or reduction of waste generation at the source. Source reduction activities and techniques include substitution of less hazardous materials, process optimization or modification, technology changes and administrative changes (inventory control), and housekeeping practices (material segregation). Source reduction results in reducing or eliminating potential waste material exiting from a process.

Spent Nuclear Fuel. Fuel that has been withdrawn from a nuclear reactor following irradiation, but that has not been reprocessed to remove its constituent elements.

State-Only Dangerous Waste. Any other hazardous waste not specifically regulated under TSCA or RCRA, such as used oil, that may be regulated by Washington State Department of Ecology (Ecology) under Washington Administrative Code (WAC) 173-303.

Transuranic Waste. Without regard to source or form, waste that is contaminated with alpha-emitting transuranium radionuclides with half-lives greater than 20 years and concentrations greater than $100 \mathrm{nCi} / \mathrm{g}$ at the time of assay. Heads of Field Elements can determine that other alpha contaminated wastes, peculiar to a specific site, must be managed as TRU (DOE, 1988a).

Treatment. Any method, technique, or process (including neutralization) designed to change the physical, chemical, or biological character or composition of any hazardous, radioactive, or sanitary waste so as to neutralize such waste, to recover energy or material resources from the waste, or to render such waste nonhazardous; safer to transport, store, or dispose; or amenable for recovery or storage; or reduced in volume.

TSCA-Regulated Waste. Wastes, both liquid and solid, containing more than 50 parts per million (ppm) of Polychlorinated Biphenyls (PCBs) or PCBs regulated for disposal (DOE, 1996a).

Waste Reduction. Reduction of the total amount of waste that is generated and disposed of by DOE operations through waste minimization and treatment activities.

Waste Minimization. Elimination or minimization of the generation of waste before treatment, storage, or disposal. Waste minimization is any source reduction or recycling activity that results in (1) reduction of total volume of waste, (2) reduction of toxicity of waste, or (3) both, as long as that reduction is consistent with the general goal of minimizing present and future threats to human health and the environment.

Waste Minimization Assessment. An evaluation and appraisal of a process, activity, or operation to identify potential waste minimization opportunities. 


\section{DISTRIBUTION}

\section{Number of Copies}

\section{ONSITE}

15

\section{U.S. Department of Energy, Richland Operations Office}
A. V. Beard
S7-55
M. A. Barnard
K8-50
H. E. Bilson
R3-81
D.W. Bowser
A2-22
E. M. Bowers
S7-55
M. E. Burandt
K8-50
D. H. Chapin
R3-79
M. S. Collins
A5-18
G. Ellis-Balone
A5- 15
C. A. Hansen
S7-41
M. R. Hahn
R3-79
R. S. Mercado
A2-45
J. H. Zeisloft
H0- 12
Hanford Technical Library
P8-55
Public Reading Room
$\mathrm{H} 2-53$

B\&W Hanford Company

T. G. Beam

S6-71

J. E. Bramson

T5-54

F. J. Carvo

N1-41

T. A. Dillhoff

N2-57

T. A. Grabner

S6-60

K. A. Hadley

R3-56

A. E. Hill

N2-57

G. J. LeBaron

S6-15

B. B. Nelson-Maki

T5-54

J. R. Robertson

T5-54

D. E. Rasmussen

N1-47

M. M. Serkowski

L1-05

L. O. Waggoner

S0-19 
DOE/RL-91-31, Rev. 4

Distribution (Continued)

\section{Number of Copies}

\section{ONSITE}

1

B\&W Protec, Inc.

M. B. Jaeger

G3-40

3

Bechtel Hanford Inc.

D. K. Duvon

X1-86

R. J. Landon

H0-18

G. S. Robinson

HO-02

1

DE\&S Hanford. Inc

D. J. Watson

X3-79

4

Dyncorp Tri-Cities Services, Inc.

B. J. Dixon

G3-26

K. C. Hinkelman

G1-10

D. L. Klages

G3-26

C. E. Marple

N1-23

Fluor Daniel Hanford

B. M. Akers

G5-54

J. W. Golden

N1-26

C. G. Mattsson

N1-26

A. G. Miskho

H6-23

K. J. Svoboda

N1-26 
DOE/RL-91-31, Rev. 4

Distribution (Continued)

\section{Number of Copies}

\section{QNSITE}

2

Eluor Daniel Northwest

R. A. Del Mar

E6-40

R. L. Newell

B7-41

1

Hanford Environmental Health Foundation

S. M. McInturff

H1-77

3

Lockheed Martin Hanford Corp.

J. S. Conrad

T4-08

K. A. Elsethagen

S5-03

P. C. Miller

R1-51

4

Lockheed Martin Services, Inc

T. M. Holmes

G3-32

Document Processing Center (1)

A3-94

Central Files (1)

B1-07

Correspondence Control (1)

A3-01

2

Numatec Hanford Corp.

D. J. Alexander

S3-31

R. A. Kaldor

H5-25

1

Pacific Northwest National Laboratory

E. A. Raney

P7-79

Distribution-3 
DOE/RL-91-31, Rev. 4

Distribution (Continued)

Number of Copies

ONSITE

24 Waste Management Federal Services of Hanford, Inc.

D. J. Alexander S3-31

B. M. Barnes T4-04

M. D. Betsch H6-06

H. C. Boynton T4-52

J. B. Buckley, Jr. T3-04

D. E. Clark H6-06

D. L. Flyckt S6-71

B. Griffin II T6-30

C. R. Haas $\quad$ T3-28

N. O. Hinojosa X3-67

S. C. Howald $\quad$ H6-06

D. E. McKenney H6-06

D. S. Merry H6-06

D. H. Nichols H6-06

S. L. Payton S6-71

B. G. Place H6-06

F. C. Schmidt $\quad$ S6-30

M. M. Seay S6-31

P. Segall H6-06

Y. M. Shehadeh H6-06

R. W. Szelmeczka L6-05

G. C. Triner T3-05

O. J. Valero H6-06

J. L. Westcott T3-04

1 Waste Management Federal Services Northwest

S. E. Myers H1-12 


\subsection{OVERVIEW}

The purpose of this plan is to specify the requirements for Hanford Site contractors to prevent pollution from entering the environment, to conserve resources and energy, and to reduce the quantity and toxicity of hazardous, radioactive, mixed and sanitary waste releases to the environment at the Hanford Site. The Pollution Prevention Awareness Program Plan required by DOE 5400.1 (DOE 1988b) is included in the Hanford P2/WMin Program. The plan is primary in a hierarchical series that includes the Hanford Site Waste Minimization and Pollution Prevention Awareness Program Plan, Prime contractor implementation plans, and the Hanford Site Guide for Preparing and Maintaining Generator Group Pollution Prevention Program Documentation (DOE-RL, 1997a) describing programs required by RCRA 3002(b) and 3005(h) (RCRA and EPA, 1994)

Hanford Site's missions are to safely clean up and manage its legacy wastes, and to develop and deploy science and technology. Through these missions the Hanford Site will contribute to economic diversification of the region.

Hanford Site's environmental management or cleanup mission is to protect the health and safety of the public, workers, and the environment; control hazardous materials; and utilize the assets (people, infrastructure, site) for other missions. Hanford Site's science and technology mission is to develop and deploy science and technology in the service of the nation including stewardship of the Hanford Site. Pollution Prevention is a key to the success of these missions by reducing the amount of waste to be managed and identifying/implementing cost effective waste reduction projects.

Hanford Site's original mission, the production of nuclear materials for the nation's defense programs, lasted more than 40 years, and like most manufacturing operations, Hanford Site's operations generated large quantities of waste and pollution. However, the by-products from Hanford Site operations pose unique problems like radiation hazards, vast volumes of contaminated water and soil, and many contaminated structures including reactors, chemical plants and evaporation ponds

The cleanup activity is an immense and challenging undertaking, which includes characterization and decommissioning of 149 single shell storage tanks, treating 28 double shell tanks, safely disposing of over 2,100 metric tons of spent nuclear fuel stored on the Hanford Site, removing numerous structures, and dealing with significant solid waste, ground water, and land restoration issues.

In fulfilling their responsibilities to accomplish Hanford Site's missions efficiently and in a manner promoting the protection of the workers, the public, and the environment, contractors and subcontractors must systematically integrate safety into all management and work practices at all levels so that missions are accomplished in accordance with Integrated Environment, Safety and Health Management System (ISMS) guidance. The ISMS core functions establish a framework for the evaluation of any work activity that could adversely affect the worker, the public, or the environment, and pollution prevention is the preferred approach to environmental management. 
The Hanford Site P2/WMin Program reflects the national and DOE waste minimization and pollution prevention goals and policies and represents an ongoing effort to ensure P2/WMin is part of the Hanford Site operating philosophy.

In accordance with these policies, a hierarchical approach to environmental management has been adopted and is applied to all polluting and waste generating activities. Waste minimization through source reduction is the first priority in the Hanford Site P2/WMin Program, followed by environmentally safe recycling. Treatment to reduce the quantity, toxicity, and mobility of waste is considered only when source reduction or recycling are not possible or practical. Environmentally safe disposal is the last option.

This plan applies to all affected Hanford Site contractors, activities, and operations. Affected Hanford Site contractors include Fluor Daniel Hanford, Inc. (FDH), as the management and integration contractor of the Project Hanford Management Contract, Pacific Northwest National Laboratory (PNNL), and Bechtel Hanford, Inc., (BHI). These Hanford Site contractors are expected to meet the elements of this document. The Hanford Site contractors are responsible for administering P2/WMin guidance, instruction, and procedures for operations.

This plan will be reviewed annually and revised as necessary. At a minimum it will be revised every three years. 


\subsection{POLICY AND REGULATORY BACKGROUND}

\subsection{U.S. Department of Energy}

The RL Manager and senior management are committed to preventing pollution and minimizing the generation of waste. Management shall provide adequate personnel, budget, training, and material on a continuing basis to ensure that the objectives of the P2/WMin program are met.

The RL Manager has issued a written policy that establishes a commitment to implement an effective P2/WMin Program at the Hanford Site, the DOE 1996 Pollution Prevention Program Plan (DOE, 1996a) and all applicable executive orders (EOs). The statement of policy is included in Appendix $\mathbf{A}$ of this plan.

\subsection{Contractor P2/WMin Program}

In accordance with the laws and policies, DOE orders, EOs, regulatory requirements, and Washington State administrative codes listed in Appendix B, as applicable, the companies of FDH, BHI, and PNNL shall develop and maintain a pollution prevention program with the following characteristics:

- Includes written and issued implementation plans describing how the contractors plan to achieve the $\mathrm{P} 2 / \mathrm{WM}$ in requirements

- Implements the 1996 Pollution Prevention Program Plan (DOE, 1996a) and other U.S. Department of Energy-Headquarters (DOE-HQ) documents that provide the principal guidance and strategy for fully implementing a pollution prevention program

- Is reviewed annually and updated at least every three years

- Provides pollution prevention guidance, instructions, and procedures applicable to their operations. 
DOE/RL-91-31, Rev. 4

This page intentionally left blank. 


\subsection{ORGANIZATIONAL STRUCTURE}

Figure 3-1 shows the Hanford Site P2/WMin organizational structure. The overall management responsibility for the Hanford Site resides with $\mathrm{RL}$. The $\mathrm{RL}$ manager is responsible for leadership and direction of Hanford Site P2/WMin efforts. The RL Waste Programs Division (WPD) is responsible for the overall Hanford Site P2/WMin program. A P2/WMin program manager has been established in the WPD who is responsible for the oversight and interface of P2/WMin program activities, reviewing and coordinating Hanford Site P2/WMin efforts, and ensuring the implementation of contractors' P2/WMin programs. The RL P2/WMin team assists the $\mathrm{RL}$ program manager in coordination of their assigned contractor responsibilities, including return on investment (ROI) proposal review and approval and ROI project reporting.

Waste Management Federal Services of Hanford, Inc. (WMH), a subcontractor to FDH, has been assigned the lead role in coordinating the Hanford Site P2/WMin Program. In response to this assignment, the WMH $\mathrm{P} 2 / \mathrm{WMin}$ organization meets regularly with $\mathrm{FDH}, \mathrm{RL}$, and representatives from the other Hanford Site contractors. The main objective of the WMH P2/WMin organization is to support the coordination and implementation of the Hanford Site P2/WMin Program activities.

Each contractor is required to develop an appropriate organization to administer the $\mathrm{P} 2 / \mathrm{WM}$ in program. The primary function of these P2/WMin organizations is to implement the key elements of the sitewide or generator-specific program identified in the DOE 1996 Pollution Prevention Program Plan (DOE, 1996a) and this document. 
DOE/RL-91-31, Rev. 4

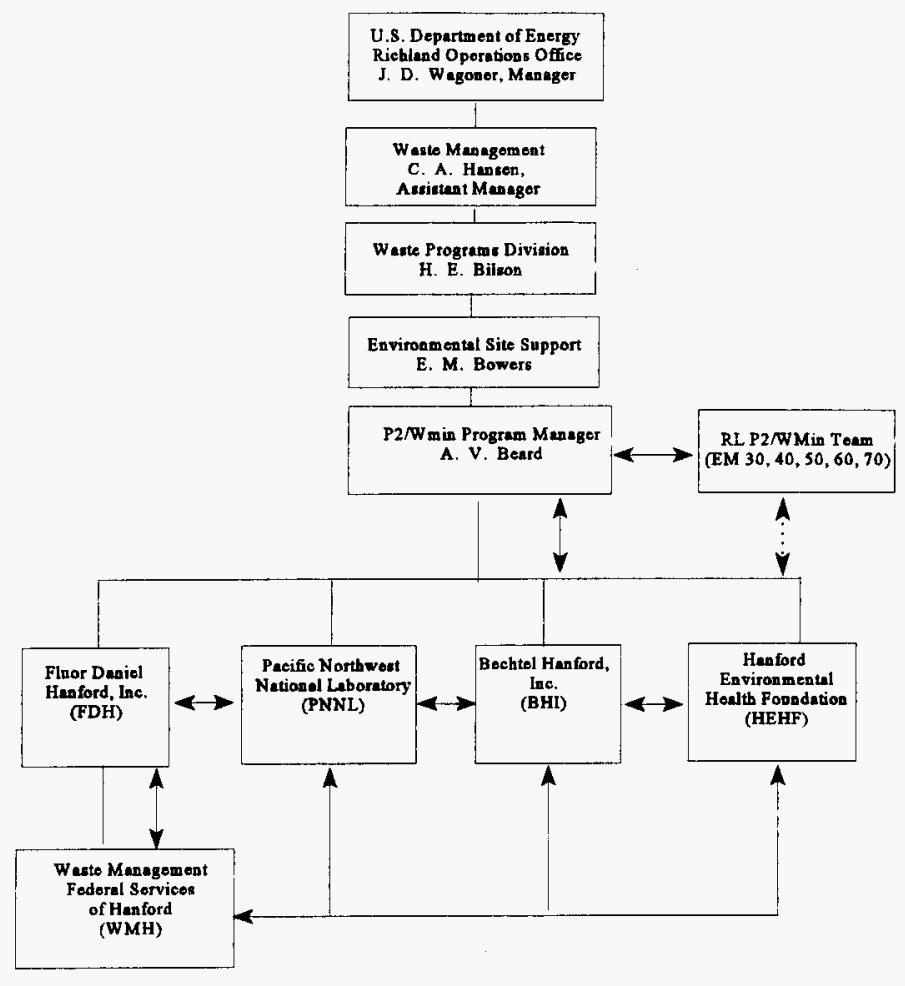

Figure 3-1. Hanford Site P2/WMin Program Organizational Chart. 


\subsection{PROGRAM OBJECTIVES/GOALS}

A P2/WMin program shall be developed that implements the eighteen elements of the P2/WMin Activity Plan outlined in the DOE 1996 Pollution Prevention Program Plan (DOE, 1996a), identified below and discussed in Section 5.0. Eighteen activities are interdependent and are necessary to sustain a P2/WMin program that meets regulatory, DOE, and State requirements while achieving reductions in waste generation and releases to the environment.

\subsection{Objectives to be Immediately Implemented}

The following six activities should have been implemented by Fiscal Year (FY) 1998. Implementation will allow the Hanford Site to focus resources on the most critical aspects of the P2/WMin program to achieve the waste reductions specified by the Secretary. The six activities are:

- Establish senior management commitment

- Set quantitative source reduction and recycling goals

- Institute performance measures

- Implement cost-saving pollution prevention projects

- Design pollution prevention into new products, processes, and facilities

- Ensure that programs comply with federal, state, and departmental directives.

\subsection{Near-Term and Out-Year Objectives}

Implementation of the six near-term and six out-year activities will continue the development and strengthening of the Hanford Site P2/WMin Program that has not only reduced waste generation but has reduced environmental impacts and risks as well as the mortgage and support costs related to future waste management activities.

The six activities designated as near-term are the following:

- Implement consistent generator-specific pollution prevention programs

- Reduce releases of toxic chemicals

- Establish pollution prevention budgets

- Perform pollution prevention cost-benefit analyses 
- Facilitate technology transfer and information exchange

- Implement pollution prevention employee training and awareness programs.

The six activities designated as out-year are the following:

- Implement environmentally sound pollution prevention procurement practices

- Integrate pollution prevention into Research, Development, Demonstration, Testing, and Evaluation (RDDT\&E) programs

- Ensure consistent policies and procedures

- Implement pollution prevention outreach and public involvement

- Develop pollution prevention incentives programs

- Promote regulatory review and reform.

The near term objectives are to be implemented by FY 1999, and the out-year objectives are to be implemented by FY 2000 .

\subsection{Goals}

Establishing goals is essential to a successful P2/WMin program. Goals provide management with tangible targets and provide a basis for measuring progress. The Secretary of Energy, in a May 1996 memorandum (DOE, 1996b), established waste reduction, recycling, and affirmative procurement goals for the DOE complex. This memorandum is presented in Appendix C.

Specific goals were established at the Hanford Site to meet the Secretary of Energy goals. Hanford Site goals for FYs 1998 and 1999 are listed in Table 4-1.

In addition to the goals in Table 4-1, annual quantitative waste reduction goals will be established for LLWs generated by cleanup/stabilization activities (DOE, 1988). The waste generation projection, if available, for the upcoming year should be used as the baseline. Cleanup/Stabilization operations should also establish the following goals (DOE, 1997):

- Goals should be established for cleanup activities such as weapons dismantlement, decontamination and decommissioning, legacy wastes, and contaminated site cleanup.

- Sites should explore mechanisms to quantify and report waste minimization progress for the reduction of newly generated secondary wastes from primary (already generated) wastes. 
DOE/RL-91-31, Rev. 4

Table 4-1

Hanford Site Goals

\begin{tabular}{|c|c|c|c|c|c|c|c|}
\hline \multirow{2}{*}{ Cat. } & \multirow{2}{*}{ Goal } & \multirow{2}{*}{$\frac{1993}{\text { Qty. }}$} & \multicolumn{2}{|c|}{ FY 1998 Goal } & \multicolumn{2}{|c|}{ FY 1999 Goal } & \multirow{2}{*}{$\frac{\text { By 12-31-99 }}{\text { DOE-HQ Reduction Goals }}$} \\
\hline & & & Qty. & $\%$ Reduction & Qty. & $\%$ Reduction & \\
\hline \multirow{5}{*}{$\begin{array}{l}\mathrm{R} \\
\mathrm{O} \\
\mathrm{U} \\
\mathrm{T} \\
\mathrm{I} \\
\mathrm{N} \\
\mathrm{E}\end{array}$} & $\begin{array}{l}\text { Reduction of Toxic Chemical Release } \\
\text { Inventory (lb) }\end{array}$ & 14 & 7 & 50 & 7 & 50 & $50 \%$ \\
\hline & Reduction of LLW Generation $\left(\mathrm{m}^{3}\right)$ & 3867 & 1933.5 & 50 & 1933.5 & 50 & $50 \%$ \\
\hline & Reduction of MLLW Generation $\left(\mathrm{m}^{3}\right)$ & 498 & 325 & 35 & 249 & 50 & $50 \%$ \\
\hline & $\begin{array}{l}\text { Reduction of Hazardous Waste } \\
\text { Generation (mt) }\end{array}$ & 218 & 109 & 50 & 109 & 50 & $50 \%$ \\
\hline & $\begin{array}{l}\text { Reduction of Sanitary Waste Generation } \\
\text { (mt) }\end{array}$ & 7124 & 4773 & 33 & 4773 & 33 & $33 \%$ \\
\hline \multirow[t]{2}{*}{$\begin{array}{l}\text { A } \\
\text { L } \\
\text { L }\end{array}$} & Sanitary Waste Recycling & $\begin{array}{l}\text { Baseline } \\
\text { Established } \\
\text { Annually }\end{array}$ & & 33 & & 33 & $33 \%$ \\
\hline & $\begin{array}{l}\text { Increase Affirmative Procurement of } \\
\text { FPA-Designated Recycled Products }\end{array}$ & & & $\begin{array}{l}80 \% \text { of total } \\
\text { purchases }\end{array}$ & & $\begin{array}{l}100 \% \text { of total } \\
\text { purchases }\end{array}$ & $100 \%$ \\
\hline
\end{tabular}


- Cleanup and stabilization sites must evaluate methods to reduce secondary waste generation and reduce, by recycling and reuse, the amount of waste requiring disposal. Sites are encouraged to set waste segregation goals to keep waste disposal costs as low as possible. Mixed wastes are to be carefully avoided due to the high life cycle cost to dispose of this waste type. 


\subsection{HANFORD SITE PROGRAM DESCRIPTION}

For the Hanford Site to have a successful P2/WMin program and meet goals and objectives, the activities below should be incorporated into the FDH, BHI, and PNNL P2/WMin programs.

\subsection{Establishment of Senior Management Commitment}

Strong and visible senior management is necessary for a successful P2/WMin program. To demonstrate their commitment each Hanford Site contractor shall clearly define expectations, goals, accountability, and the providing of adequate resources

\subsection{Institute Performance Measures}

Pollution prevention performance measures provide essential feedback on progress made toward achieving goals. They also allow for program readjustment if progress is considered inadequate. In order to provide the Hanford Site progress toward meeting the Secretary of Energy's goals the Hanford Site P2/WMin Program Office (WMH) will develop and issue quarterly performance measures. These performance measures are listed below:

Performance Measures For Routine Operations

- Quantity of radioactive waste reduced

- Quantity of mixed waste reduced

- Quantity of hazardous and sanitary waste reduced

- Quantity of EPCRA 313 toxic chemical releases and off-site transfers reduced.

Performance Measures For All Operations (Routine and Cleanup/Stabilization)

- Percentage of sanitary waste recycled

- Percentage of total dollars spent on purchasing EPA-designated products containing recovered materials.

5.3 Perform Waste Minimization Assessments and Implement High Return-on-Investment P2/WMin Projects

Source reduction and recycling goals can be achieved when pollution prevention projects are aggressively implemented. Waste Minimization Assessments (WMAs) identify cost-effective 
techniques to reduce waste generation and pollutants. The preferred assessment method at the Hanford Site is the P2OA conducted in accordance with the guidance provided in Pollution Prevention Opportunity Assessments: A Training and Review Guide (DOE-RL, 1996a). Other evaluation methods, such as value engineering studies, engineering evaluations, and P2/WMin in design assessments, are also effective. Each contractor should evaluate the opportunities resulting from the WMAs conducted. Contractors should prepare pollution prevention proposals that provide a high ROI through reducing waste and associated management costs and submit them to RL for approval. Guidance for preparing ROI proposals and the acceptance criteria for an ROI proposal are addressed in Return on Investment (ROI) Proposal Preparation Guide (DOE-RL, 1997b).

\subsection{Design Pollution Prevention Into New Products, Processes, and Facilities}

According to DOE Orders 5820.2A and 430.1, P2/WMin should be considered when designing new facilities or modifying existing facilities that are capable of generating all waste types and must be considered when designing new facilities or modifying existing facilities that are capable of generating LLW. P2/WMin must also be considered when installing new equipment or modifying existing equipment. Design for pollution prevention should encompass the entire life cycle of a project. Each contractor should ensure P2/WMin is considered when designing new facilities or modifying existing facilities.

The guidance for conducting pollution prevention assessments on design projects is the Good Practice Guide, Waste Minimization/Pollution Prevention (DOE, 1996c).

5.5 Develop and Maintain Hanford Site Pollution Prevention Programs that Comply with Federal, State and Departmental Directives

Certain Hanford Site activities must be performed to comply with Federal, State, and Departmental directives. Such activities include sitewide coordination, planning, reporting, training, employee awareness, assessments, and recycling and affirmative procurement programs. Each contractor shall ensure that their P2/WMin program incorporates these requirements.

\subsection{Waste Minimization/Pollution Prevention Techniques}

As stated above, the Hanford Site P2/WMin Program uses a hierarchical approach to environmental management, placing primary importance on source reduction efforts to prevent pollution and eliminate or reduce the generation of waste. Potential pollutants and wastes that cannot be eliminated or minimized are evaluated for recycling. Treatment to reduce the quantity, toxicity, or mobility of waste before storage or disposal will be considered only when prevention or recycling are not possible or practical. Environmentally safe disposal is the last option.

The techniques discussed below will be employed by the Hanford Site contractors to prevent pollution and minimize the generation of waste. 


\subsubsection{Inventory Management}

Inventory management or control techniques will be used to reduce waste resulting from excess or out of date chemicals and hazardous substances. Where necessary, techniques will be implemented to reduce inventory size of hazardous chemicals, size of containers, and amount of chemicals, while increasing inventory turnover.

As established through a Chemical Management System, acquisition of new chemical supplies shall be documented in a controlled process that addresses, as appropriate, the following that relate to pollution prevention (DOE-RL, 1997c):

- Need for the chemical

- Availability of nonhazardous or less hazardous substitutes or alternatives

- Amount of chemical required

Excess chemicals shall be managed in accordance with contractor chemical management procedures. Excess chemicals that are still viable will be handled through an excess chemical program. Material control operations should also be revised or expanded to reduce raw material and finished product loss, waste material, and damage during handling, production, and storage. The inventory management techniques should include determining:

- If existing inventory management techniques are in accord with existing pollution prevention guidelines, regulatory guidelines, and DOE orders

- How existing inventory management procedures can be applied more effectively

- Whether new techniques should be added to or substituted for current procedures

- If the review and evaluation approval procedures for the purchase of materials should be revised

- If additional employee training in the principles and inventory management is needed

- How specifications for the review and revision of procurement limit the purchase of environmentally sound products

- How to increase the purchase of recycled products.

\subsubsection{Maintenance Program}

Equipment maintenance programs should be periodically reviewed to determine whether improvements in corrective and preventive maintenance can reduce equipment failures that 
generate waste. The methods for maintenance cost tracking and preventive maintenance scheduling and monitoring should be examined. Maintenance procedures should be reviewed to determine which are contributing to the production of waste in the form of process materials, scrap, and cleanup residue, and the need for revising operational procedures, modifying equipment, and source segregation and recovery should be determined.

\subsubsection{Recycling and Reuse}

Recycling of all waste types shall be considered. Opportunities for reclamation and reuse of waste materials will be explored whenever feasible. Decontamination of tools, equipment, and materials for reuse or recycle will be used as much as feasible to minimize the amount of waste for disposal. Impediments to recycling, whether regulatory or procedural, should be challenged to enable generators to recycle whenever possible.

\subsubsection{Segregation}

When waste is generated, proper handling, containerization, and segregation techniques will be employed to minimize contamination resulting in the generation of unnecessary waste.

\subsubsection{Work Planning}

Pre-job planning will be completed to determine what materials and equipment are needed to perform all other required work onsite. One objective of this planning is to prevent pollution and minimize the amount of waste that may be generated and to use only what is absolutely necessary to accomplish the work. Planning should also be done to prevent mixing of materials or waste types.

\subsection{Pollution Prevention Reporting and Tracking}

\subsubsection{Pollution Prevention Documentation Reporting Systems}

Hanford Site contractors or Hanford Site contractor waste generator groups shall prepare, maintain and submit the program documentation and reports required in the Hanford Site Guide for Preparing and Maintaining Generator Group Pollution Prevention Program Documentation (DOE-RL 1997a).

\subsubsection{Pollution Prevention Tracking Systems}

If not available, each Hanford Site contractor shall develop a tracking system to identify waste generation data and pollution prevention opportunities in order to provide essential 
feedback to successfully guide future efforts. The data collected by the system will be used for internal reporting, will be capable of providing feedback on the progress of the Pollution Prevention Program, including the results of the implementation of pollution prevention technologies, and will facilitate reporting pollution prevention data and accomplishments to the DOE, EPA, and Ecology.

The system shall track waste from point of generation to point of final disposition (cradle to grave). The system shall also permit the tracking of hazardous substances from the point of site entry to final disposition to comply with environmental regulations and reporting requirements. The system should collect data on input material, material usage, type of waste, volume, hazardous constituents, generating system, generation date, waste management costs, and other relevant information.

\subsection{Reduce Releases of Toxic Chemicals}

Reduction of releases of toxic chemicals is addressed as a Hanford Site goal in Section 4.3.

\subsection{Establish Pollution Prevention Budgets}

Sufficient funding is an essential aspect of managing a P2/WMin program. Each Hanford Site contractor shall develop budgets for the activities that will help the contractor generator groups achieve the 18 objectives. Separate identifiable funding shall be established within individual cost account plans depending on the contractor funding needs.

The sitewide program is funded directly from DOE-HQ. In the majority of the cases, the funding required for pollution prevention activities by generator groups is too small to require individual budget requests. Generator groups are required to integrate pollution prevention into proposed projects that will generate waste. Generator groups will also maintain program budgetary documentation as discussed in the Hanford Site Guide for Preparing and Maintaining Generator Group Pollution Prevention Program Documentation (DOE-RL, 1997a).

\subsection{Perform Pollution Prevention Cost-Benefit Analyses}

If life cycle costs for the Hanford Site are not available, a system should be developed by each contractor that accounts for the "true cost" of waste that is generated by the company and permits meaningful reviews and audits to be conducted.

The system should consider the fixed and variable costs arising from:

- Under use of raw materials found in the waste stream

- Management of the wastes that are generated 
- Waste disposal

- Third-party liabilities if the waste is improperly disposed.

Associated costs should include personnel, record keeping, transportation (including onsite movement), pollution control equipment, treatment, storage, disposal, liability, compliance, and oversight costs.

The costs derived from the cost accounting system should be included in proposals, planning, and budgeting. Departments and managers should be accountable for the "true" waste management costs for the wastes they generate

\subsection{Facilitate Technology Transfer and Information Exchange}

Hanford Site's missions are to safely clean up and manage its legacy wastes and to develop and deploy science and technology. The core requirement of the technology transfer is implementation of the National Competitiveness Technology Transfer Act of 1989 (Public Law 101-189). Activities involving technology transfer should be referred to contractor technology transfer organizations. These organizations are directed to coordinate all available technology transfer mechanisms including management of intellectual property, negotiating licenses, entering into Cooperative Research and Development Agreements, and forming partnerships with private-sector business for commercialization of Hanford Site technologies to optimize support for both the Hanford Site cleanup mission and local and regional economic development.

Technology transfer also supports the Hanford Site cleanup mission by identifying and assisting facilities to acquire state-of-the-art technologies, and those requiring additional development, to meet specific cleanup challenges. Opportunities for transfer of technologies specific to P2/WMin programs may develop from information exchange systems, workshops, or topical conferences. Direct exchanges of technologies among facilities may be acceptable but the technology transfer organizations should be consulted to ensure proper handling of intellectual property.

All program staff are encouraged to make regular use of the U. S. DOE Pollution Prevention Information Clearinghouse. Contractors also participate in business, education, and government forums that are designed to provide technical assistance and exchange P2/WMin information. Also, onsite meetings will be held to promote information exchange.

\subsection{Implement Pollution Prevention Awareness Programs}

A successful P2/WMin program requires employee commitment. By educating employees in the principles and benefits of P2/WMin, solutions to current and potential environmental management problems can be found. The broad objective of pollution prevention awareness is to educate Hanford Site employees in all environmental aspects of activities occurring at the Hanford 
Site, in their community, and in their homes. Each contractor shall define and implement a pollution prevention awareness program that incorporates the following:

- Make employees aware of general environmental activities and hazards at the Hanford Site and pollution prevention program requirements, goals, and accomplishments

- Inform employees of specific environmental issues

- Train employees on their responsibilities in pollution prevention

- Recognize employees for efforts to improve environmental conditions through pollution prevention

- Encourage employees to participate in pollution prevention.

\subsection{Implement Environmentally Sound Pollution Prevention Procurement Practices}

Each contractor shall implement procurement practices that ensure compliance with regulatory, state, and EOs, and other requirements for the purchase of products with recovered materials and include the elimination of the purchase of ozone depleting substances and minimize the purchase of hazardous substances.

\subsection{Integrate Pollution Prevention Into Research, Development, Demonstration, Testing, and Evaluation Programs}

Waste generation and RDDT\&E should be integrated to ensure that P2/WMin RDDT\&E projects offering the greatest technical benefit are available to generator organizations. Some P2/WMin options may require development work before being implemented. The options may also identify process inefficiencies that offer the potential for significant waste reduction, but specific process modifications may require R\&D work before implementation can be scheduled. Funding requests should be coordinated through the Technology Development Program (EM-50).

\subsection{Assure Consistent Policies, Orders, and Procedures}

Policies and procedures should be updated to reflect a focus on integrating P2/WMin objectives into contractor activities. Existing procedures for Hanford Site activities will be reviewed by Hanford Site contractors to determine whether the elimination or revision of procedures can contribute to the reduction of waste. This will include incorporating P2/WMin into all appropriate onsite work procedures. Changes to procurement procedures to require affirmative procurement of EPA designated recycled products and reduction of procurement of ozone-depleting substances will also be made by Hanford Site contractors in accordance with EO requirements and the DOE affirmative procurement goals. 
In addition, each contractor shall review procedures for control and purchase of hazardous substances to determine whether less harmful materials may be used. All other applicable procedures will be reviewed and revised to include P2/WMin. The revision and review of procedures for P2/WMin opportunities will be fully documented and incorporated as part of Hanford Site employee training programs.

\subsection{Implement Pollution Prevention Outreach and Public Involvement}

Each contractor should communicate waste minimization successes and information to employees and the community through outreach. Public involvement of each contractor will help to establish public confidence and trust, increase awareness of environmental issues, and promote the reduction of waste. Hanford Site contractors are encouraged to participate in the organizing of activities such as Earth Day and the local schools' Ambassadors program and to publish information externally to help increase awareness and public trust. Public and stakeholder participation should also be sought for projects and program elements to encourage community involvement and to develop a broad base of input and understanding of relevant pollution prevention issues.

\subsection{Develop Pollution Prevention Incentives Programs}

Incentives are necessary to stimulate and maintain interest in changing processes and activities. As addressed in Section 5.12, "Implement Pollution Prevention Awareness Programs," each contractor shall develop programs to recognize an individual's or organization's pollution prevention achievements and suggestions that improve and promote P2/WMin.

\subsection{Promote Regulatory Review and Reform}

DOE orders, regulatory and state requirements, though providing significant benefits to the public, can sometimes hinder $\mathrm{P} 2 / \mathrm{WM}$ in initiatives. Conservative requirements at times result in expensive treatment and disposal for waste that could otherwise be recycled, reused, or handled by commercial treatment and disposal facilities. Risks associated with hazardous and radioactive wastes need to be evaluated considering the latest scientific evidence. The contractors shall identify to RL and to DOE-HQ potential changes in regulations that would promote cost effective $\mathrm{P} 2 / \mathrm{WM}$ in as opposed to expensive treatment, storage, or disposal practices. 


\subsection{RESOURCES AND PROGRAM EVALUATION}

\subsection{Resources}

Hanford Site contractors must ensure resources are committed to meet the requirements outlined in this plan and specified contractually.

\subsection{Program Evaluation}

Each Hanford Site contractor shall evaluate their P2/WMin program periodically and report the findings to RL. This information will be used to establish future P2/WMin goals and program objectives. The information will also be used to determine changes to this plan. 
DOE/RL-91-31, Rev. 4

This page intentionally left blank. 


\subsection{REFERENCES}

DOE, 1988a, Radioactive Waste Management, DOE Order 5820.2A, U.S. Department of Energy, Washington, D.C.

DOE, 1988b, General Environmental Protection Program, DOE Order 5400.1, U.S. Department of Energy, Washington, D.C.

DOE, 1996a, Pollution Prevention Program Plan, DOE/S-0118, U.S. Department of Energy, Office of the Secretary, Washington, D.C.

DOE, 1996b, O'Leary, Hazel R., Departmental Pollution Prevention Goals, DOE Memorandum, U.S. Department of Energy, Washington, D.C., May 3, 1996.

DOE, 1996c, Waste Minimization/Pollution Prevention, Good Practice Guide GPG-FM-025A, U. S. Department of Energy, Washington, D.C., December 1996.

DOE, 1997, Grumbly, Thomas P., Guidance for Preparation for Site Pollution Prevention Plans, DOE Memorandum, U. S. Department of Energy, Washington, D.C., January 1997.

DOE-RL, 1996a, Pollution Prevention Opportunity Assessments - A Training and Resource Guide, DOE/RL-96-80, U.S. Department of Energy, Richland Operations Office, Richland, Washington, November 1996.

DOE-RL, 1997a, Hanford Site Guide for Preparing and Maintaining Generator Group Pollution Prevention Program Documentation, DOE/RL-95-103, Rev. 2, U.S. Department of Energy, Richland Operations Office, Richland, Washington, November 1997.

DOE-RL, 1997b, Return on Investment (ROI) Proposal Preparation Guide, DOE/RL-97-12, Rev. 1, U.S. Department of Energy, Richland Operations Office, Richland, Washington, September 1997.

DOE-RL, 1997c, letter to J. D. Wagoner, Chemical Management System Plans and Implementation, letter, August 26, 1997

EPA, 1994, Hanford Facility Dangerous Waste Permit, Permit Number WA7890008967, Hazardous and Solid Waste Amendments Portion, U. S. Environmental Protection Agency, Seattle, Washington

RCRA, Resource Conservation and Recovery Act of 1976, as amended, 42 USC 6901 et seq.

TSCA, Toxic Substances Control Act of 1976, as amended, 15 USC 2601 et seq.

WAC 173-303, Dangerous Waste Regulations, Publication No. 92-91, A mended November 1995, Washington State Department of Ecology, Olympia, Washington. 
DOE/RL-91-31, Rev. 4

This page intentionally left blank. 
DOE/RL-91-31, Rev. 4

APPENDIX A

U.S. DEPARTMENT OF ENERGY-RICHLAND OPERATIONS OFFICE POLLUTION PREVENTION POLICY 
DOE/RL-91-31, Rev. 4

This page intentionally left blank. 
DOE/RL-91-31, Rev. 4

PLF-1321.s DEFOA

pary

\section{ANNOUNCEMENT}

Department of Energy

RL No.: $\quad 94-83$

Richland Operations Office

P.O. Box 550

Richland. Washington 99352

Issued: MAY . 61994

To: AII RL and Contractor Employees

Subject: POLLUTION PREVENTION POLICY

On August 3, 1993, the President signed Executive Order 12856, "Federal

Compliance with Right-to-Know Laws and Pollution Prevention Requirements. - The issuance of this Executive Order and others enumerated below represents a major injtiative on the part of the President to proclaia the Federal Government's role as the national leader in pollution prevention. I, too, an firmly comitted to ensuring incorporation of all departmental and national pollution. prevention goals in the dafly conduct of our business.

Pursuant to requirenents set forth in Executive Order 12856, it is the policy of the U.S. Department of Energy, Richland Operations Office (RL), to manage all Hanford Site facilities and operational activities in a manner that will reduce the generation of wastes and eliminate or minimize pollutants released to environmental media. To execute this policy, RL and Hanford site contractor personnel shall incorporate waste minimization and pollution prevention performance weasures and goals into all progranmatic and operational activities including, but not linited to, the design, construction, and operation of new facilities, new product acquisition, the decontanination and decomissioning of surplus facilities and other waste generating activities including site environmental restoration and reaediation work.

As a part of the implementation process, RL and Hanford Site contractors will follow the four-point priority system instituted by the Pollution Prevention Act of 1990. Additionally, Executive Order 12856 directs that voluntary goals be set to reduce total releases and the offsite transfer of Toxic Chemical Release Inventory chemicals reported under the Emergency Planning and Community Rightto-Know Act (EPCRA). RL and Hanford Site contractors will develop plans and goals to eliminate or reduce unnecessary acquisition of products containing extrenely hazardous substances or toxic chemicals and to delineate progress in reaching these goals in yearly progress reports to my Office of Environmental Assurance, Permits, and Policy. 
RL and Hanford Site contractors will also comply with Executive Order 12873, issued October 21, 1993, which requires federal agencies to expand waste prevention and recycling programs, implement affirmative procurement programs for recycled and energy efficient materials including the procurement of other environmentally preferable products and services.

RL and Hanford Site contractors will implement Executive Order 12843, issued Aprit 21, 1993, which requires federal agencies to minimize and allow for phaseout of Class I and II ozone-depleting substances.

In conclusion, RL and Hanford Site contractors will establish performance measures and goals in accordance with these Executive Orders and consistent with previous pollution prevention and waste minimization requirements contained in the 1993 Department of Energy Waste Minimization/Pollution Prevention Crosscut Plan, the Pollution Prevention Act of 1990, the Resource Conservation and Recovery Act (RCRA), 40 Code of Federal Regulations Part 264, the Hashington Administrative Code Chapters 173-303 and 173-307, and DOE Orders 5400.1 and 5820.2A.

Recognizing that pollution prevention will be strengthened in the future through the U.S. Environmental Protection Agency, the State of Washington, DOE Headquarters waste minialzation guidance, and DOE Orders, we must try harder to achieve leadership in this discipline. Pollution prevention sust become an integral part of the way work is performed at the Hanford site. Your contribution is necessary for achievement of environmental excelience at Hanford.

I have assigned the responsiblitity of ensuring compliance with this policy to the Office of Environmental Assurance, Permits, and Policy. An implementing procedure will follow. Please contact Ellen Dagan, Manager of the Pollution Prevention Progran, on 376-3811 if you have questions or need further information.

\section{Distribution}

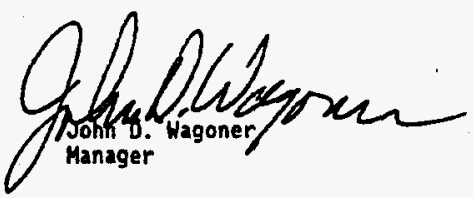


DOE/RL-91-31, Rev. 4

APPENDIX B

LEGAL AND POLICY BACKGROUND 
DOE/RL-91-31, Rev. 4

This page intentionally left blank. 
The following table provides, as applicable, the key and regulatory drivers that require the P2/WMin Program and its elements.

\begin{tabular}{|c|c|c|}
\hline Function & Driver & Effect \\
\hline $\begin{array}{l}\text { Federal } \\
\text { Procurement } \\
\text { Guidelines }\end{array}$ & RCRA 40 CFR 247 & $\begin{array}{l}\text { Encourages procurement of recovered } \\
\text { materials by the Federal Government }\end{array}$ \\
\hline $\begin{array}{l}\text { Generator } \\
\text { Manifest } \\
\text { Certification }\end{array}$ & $\begin{array}{l}\text { RCRA 3002(b), 3005(h), } \\
40 \text { CFR 262, 264-265 }\end{array}$ & $\begin{array}{l}\text { Requires generator to certify that a } \\
\text { hazardous waste minimization program is } \\
\text { in place }\end{array}$ \\
\hline $\begin{array}{l}\text { Generator } \\
\text { Biennial Report } \\
\text { Certification }\end{array}$ & $\begin{array}{l}\text { RCRA } 40 \text { CFR 262, 264- } \\
265\end{array}$ & $\begin{array}{l}\text { Requires generator to put in place a } \\
\text { hazardous waste minimization program }\end{array}$ \\
\hline $\begin{array}{l}\text { Part B Permit } \\
\text { Conditions }\end{array}$ & RCRA & $\begin{array}{l}\text { Requires generator to put in place a } \\
\text { hazardous waste minimization program }\end{array}$ \\
\hline $\begin{array}{l}\text { Liability Insurance } \\
\text { Requirements }\end{array}$ & RCRA & $\begin{array}{l}\text { Generator and facility owners and } \\
\text { operators reduce liability by reducing } \\
\text { waste }\end{array}$ \\
\hline $\begin{array}{l}\text { Land Disposal } \\
\text { Restrictions }\end{array}$ & RCRA & Increases the cost of waste management \\
\hline $\begin{array}{l}\text { Exclusion to the } \\
\text { Toxicity } \\
\text { Characteristic }\end{array}$ & RCRA & $\begin{array}{l}\text { Minimizes chlorofluorocarbon (CFC) } \\
\text { venting and encourages recycling }\end{array}$ \\
\hline $\begin{array}{l}\text { Waiver of } \\
\text { Sovereign } \\
\text { Immunity under } \\
\text { RCRA }\end{array}$ & $\begin{array}{l}\text { Federal Facilities } \\
\text { Compliance Act (FFCA) }\end{array}$ & $\begin{array}{l}\text { Government is subject to all RCRA } \\
\text { requirements with a } 3 \text { year delayed } \\
\text { effective date for mixed waste storage }\end{array}$ \\
\hline $\begin{array}{l}\text { Mixed Waste } \\
\text { Minimization } \\
\text { Reporting }\end{array}$ & FFCA & $\begin{array}{l}\text { National inventory of all mixed waste } \\
\text { including description of waste } \\
\text { minimization actions }\end{array}$ \\
\hline $\begin{array}{l}\text { Toxic Release } \\
\text { Inventory } \\
\text { Reporting }\end{array}$ & EPCRA & $\begin{array}{l}\text { Establish reporting requirements for the } \\
\text { use, storage, and on-site and off-site } \\
\text { transfers of hazardous and toxic } \\
\text { chemicals }\end{array}$ \\
\hline National Policy & $\begin{array}{l}\text { Pollution Prevention Act } \\
\text { (PPA) }\end{array}$ & $\begin{array}{l}\text { Declared pollution prevention as the first } \\
\text { choice in environmental management }\end{array}$ \\
\hline
\end{tabular}


DOE/RL-91-31, Rev. 4

\begin{tabular}{|l|l|l|}
\hline \multicolumn{1}{|c|}{ Function } & \multicolumn{1}{|c|}{ Driver } & \multicolumn{1}{c|}{ Effect } \\
\hline $\begin{array}{l}\text { Toxic Release } \\
\text { Inventory } \\
\text { Reporting }\end{array}$ & PPA & $\begin{array}{l}\text { Expands EPCRA 313 reporting } \\
\text { requirements to include source reduction } \\
\text { and recycling information }\end{array}$ \\
\hline $\begin{array}{l}\text { Increased } \\
\text { Reporting } \\
\text { Requirements }\end{array}$ & PPA & $\begin{array}{l}\text { Increases public access to information, } \\
\text { stimulating citizen enforcement and holds } \\
\text { industry to stricter standards }\end{array}$ \\
\hline $\begin{array}{l}\text { CERCLA } \\
\text { Financial Liability }\end{array}$ & $\begin{array}{l}\text { Comprehensive } \\
\text { Compensation and } \\
\text { Liability Act (CERCLA) }\end{array}$ & $\begin{array}{l}\text { Generators reduce future liability by } \\
\text { reducing waste }\end{array}$ \\
\hline $\begin{array}{l}\text { National Ambient } \\
\text { Air Quality } \\
\text { Standards }\end{array}$ & Clean Air Act (CAA) & $\begin{array}{l}\text { Promotes cutting emissions of six } \\
\text { hazardous air pollutants }\end{array}$ \\
\hline $\begin{array}{l}\text { New Source } \\
\text { Performance } \\
\text { Standards }\end{array}$ & CAA & $\begin{array}{l}\text { New plants must conform to strict } \\
\text { emission requirements }\end{array}$ \\
\hline $\begin{array}{l}\text { Phased-In } \\
\text { Requirements }\end{array}$ & CAA & $\begin{array}{l}\text { Firms must meet new, more restrictive air } \\
\text { emission standards }\end{array}$ \\
\hline $\begin{array}{l}\text { Early Reductions } \\
\text { Program }\end{array}$ & CAA & $\begin{array}{l}\text { Compliance extensions for voluntary } \\
\text { early reductions of hazardous air } \\
\text { pollutants }\end{array}$ \\
\hline $\begin{array}{l}\text { Maximum } \\
\text { Achievable } \\
\text { Control } \\
\text { Technology } \\
\text { (MACT) }\end{array}$ & CAA & $\begin{array}{l}\text { Directs EPA to consider pollution } \\
\text { prevention technologies when selecting } \\
\text { MACT }\end{array}$ \\
\hline $\begin{array}{l}\text { Clean Fuel Fleet } \\
\text { Program }\end{array}$ & CAA & $\begin{array}{l}\text { Requirement to meet clean-fuel fleet } \\
\text { vehicle emissions standards }\end{array}$ \\
\hline $\begin{array}{l}\text { Protection of } \\
\text { Stratospheric } \\
\text { Ozone }\end{array}$ & CAA & $\begin{array}{l}\text { Phase-out of CFCs, halons, and carbon } \\
\text { tetrachloride by 2000; limit on emissions } \\
\text { of ozone-depleting substances during the } \\
\text { servicing, use and disposal of equipment } \\
\text { containing those substances }\end{array}$ \\
\hline $\begin{array}{l}\text { Clean Water Act (CWA) } \\
\text { diminish the volume and toxicity of their } \\
\text { hazardous discharges }\end{array}$ \\
\hline
\end{tabular}


DOE/RL-91-31, Rev. 4

\begin{tabular}{|l|l|l|}
\hline \multicolumn{1}{|c|}{ Function } & \multicolumn{1}{|c|}{ Driver } & \multicolumn{1}{c|}{ Effect } \\
\hline $\begin{array}{l}\text { Radiation } \\
\text { Protection } \\
\text { Programs }\end{array}$ & 10 CFR 835 & $\begin{array}{l}\text { Requires the establishment of goals and } \\
\text { performance indicators for the } \\
\text { minimization of radioactive waste. It also } \\
\text { requires a waste minimization program } \\
\text { that will reduce the generation of } \\
\text { radioactive waste and spread of } \\
\text { contamination from Contamination, High } \\
\text { Contamination or Airborne Radioactivity } \\
\text { Areas }\end{array}$ \\
\hline $\begin{array}{l}\text { Significant New } \\
\text { Use Notification }\end{array}$ & TSCA & $\begin{array}{l}\text { Makes firms legally responsible to EPA } \\
\text { for voluntary waste minimization } \\
\text { commitment }\end{array}$ \\
\hline $\begin{array}{l}\text { Bans on Chemical } \\
\text { Substances }\end{array}$ & TSCA & $\begin{array}{l}\text { Eliminates feedstocks responsible for } \\
\text { certain waste streams }\end{array}$ \\
\hline $\begin{array}{l}\text { Handling and } \\
\text { Transportation } \\
\text { Requirements }\end{array}$ & Hazardous Materials & $\begin{array}{l}\text { Safety requirements raise costs of } \\
\text { transporting waste }\end{array}$ \\
\hline $\begin{array}{l}\text { Handling } \\
\text { Requirements }\end{array}$ & $\begin{array}{l}\text { Occupational Safety \& } \\
\text { Health Act (OSHA) }\end{array}$ & $\begin{array}{l}\text { Safety requirements raise costs of } \\
\text { transporting waste }\end{array}$ \\
\hline $\begin{array}{l}\text { Environmental } \\
\text { Taxes }\end{array}$ & Revenue Reconciliation \\
\hline $\begin{array}{l}\text { Research and } \\
\text { Development Tax } \\
\text { Credits }\end{array}$ & Tax Reform Act & Taxes on ozone-depleting chemicals \\
\hline $\begin{array}{l}\text { Storm water } \\
\text { Prevention Plan }\end{array}$ & CWA & $\begin{array}{l}\text { Provides for a tax credit for increasing } \\
\text { investment in research and development } \\
\text { of processes and products that reduce } \\
\text { waste }\end{array}$ \\
\hline $\begin{array}{l}\text { General } \\
\text { Protection } \\
\text { Program }\end{array}$ & DOE 5400.1 & $\begin{array}{l}\text { Requires that industrial Storm water } \\
\text { discharge facilities have an on-site } \\
\text { pollution prevention plan }\end{array}$ \\
\hline $\begin{array}{l}\text { Requires P2/WMin Plans, Annual Waste } \\
\text { Reduction Reports, and a Pollution } \\
\text { Prevention Awareness Program }\end{array}$ \\
\hline
\end{tabular}




\begin{tabular}{|c|c|c|}
\hline Function & Driver & Effect \\
\hline $\begin{array}{l}\text { Radioactive Waste } \\
\text { Management }\end{array}$ & $5820.2 \mathrm{~A}$ & $\begin{array}{l}\text { Requires Waste Management Plans } \\
\text { including actions to minimize radioactive } \\
\text { waste generation. Requires each DOE } \\
\text { LLW generator preparing a design for a } \\
\text { new process or process change to } \\
\text { incorporate principles into the design that } \\
\text { will minimize the generation of LLW. }\end{array}$ \\
\hline $\begin{array}{l}\text { Federal } \\
\text { Compliance with } \\
\text { Right-to-Know } \\
\text { Laws and } \\
\text { Pollution } \\
\text { Prevention } \\
\text { Requirements }\end{array}$ & $\begin{array}{l}\text { EO } 12856 \text { (August 3, } \\
1993 \text { ) }\end{array}$ & $\begin{array}{l}\text { Requires development of a pollution } \\
\text { prevention strategy and agency } \\
\text { development of a } 50 \text { percent reduction } \\
\text { goal in toxic chemicals releases by the of } \\
1999\end{array}$ \\
\hline $\begin{array}{l}\text { Federal } \\
\text { Acquisition } \\
\text { Recycling, and } \\
\text { Waste Prevention }\end{array}$ & $\begin{array}{l}\text { EO } 12873 \text { (October 21, } \\
\text { 1993) }\end{array}$ & $\begin{array}{l}\text { Promotes reductions in waste generation } \\
\text { through recycling and the use of recycled } \\
\text { and energy efficient materials }\end{array}$ \\
\hline $\begin{array}{l}\text { Procurement } \\
\text { Requirements and } \\
\text { Policies for } \\
\text { Ozone-Depleting } \\
\text { Substances }\end{array}$ & $\begin{array}{l}\text { EO 12843 (April 21, } \\
\text { 1993) }\end{array}$ & $\begin{array}{l}\text { Requires that Federal agencies minimize } \\
\text { and allow for phaseout of Class I and II } \\
\text { ozone-depleting substances }\end{array}$ \\
\hline $\begin{array}{l}\text { Federal Use of } \\
\text { Alternative Fueled } \\
\text { Vehicles }\end{array}$ & $\begin{array}{l}\text { EO 12844 (April 21, } \\
\text { 1993) }\end{array}$ & $\begin{array}{l}\text { Stimulates the availability, acquisition, } \\
\text { and use of alternatively-fueled vehicles } \\
\text { for Federal agencies }\end{array}$ \\
\hline $\begin{array}{l}\text { Requiring } \\
\text { Agencies to } \\
\text { Purchase Energy } \\
\text { Efficient } \\
\text { Computer } \\
\text { Equipment }\end{array}$ & $\begin{array}{l}\text { EO 12845 (April 21, } \\
\text { 1993) }\end{array}$ & $\begin{array}{l}\text { Requires that all acquisitions of } \\
\text { microcomputers meet "EPA Energy Star" } \\
\text { requirements for energy efficiency }\end{array}$ \\
\hline $\begin{array}{l}\text { Energy Efficiency } \\
\text { and Water } \\
\text { conservation at } \\
\text { federal facilities }\end{array}$ & $\begin{array}{l}\text { EO } 12902 \text { (March 8, } \\
\text { 1994) }\end{array}$ & $\begin{array}{l}\text { Requires to reduce energy and water } \\
\text { consumption from FY 1995-2005 } \\
\text { according to established baselines. }\end{array}$ \\
\hline $\begin{array}{l}\text { Dangerous Waste } \\
\text { Regulations }\end{array}$ & WAC $173-303$ & $\begin{array}{l}\text { Requires generator certification that a } \\
\text { waste minimization program is in place } \\
\text { for hazardous waste. }\end{array}$ \\
\hline
\end{tabular}


DOE/RL-91-31, Rev. 4

\begin{tabular}{|l|l|l|}
\hline \multicolumn{1}{|c|}{ Function } & \multicolumn{1}{|c|}{ Driver } & \multicolumn{1}{c|}{ Effect } \\
\hline National Policy & Energy Policy Act & $\begin{array}{l}\text { Promotes energy conservation and } \\
\text { efficiency and promote renewable energy. }\end{array}$ \\
\hline $\begin{array}{l}\text { Directs specific } \\
\text { percentage waste } \\
\text { reduction by } \\
\text { waste type }\end{array}$ & $\begin{array}{l}\text { Letter from Secretary } \\
\text { O'Leary dated May 3, } \\
\text { 1996 }\end{array}$ & $\begin{array}{l}\text { Requires site-specific pollution } \\
\text { prevention goals be established and } \\
\text { progress be tracked. }\end{array}$ \\
\hline $\begin{array}{l}\text { Radiological } \\
\text { Performance } \\
\text { Goals }\end{array}$ & $\begin{array}{l}\text { Hanford Site } \\
\text { Radiological Control } \\
\text { Manual, HSRCM-1,Rev. } \\
\text { 2, Part 3, Art. 131 }\end{array}$ & $\begin{array}{l}\text { Suggests establishing goals for } \\
\text { minimizing the generation of radioactive } \\
\text { waste. }\end{array}$ \\
\hline $\begin{array}{l}\text { Waste } \\
\text { Minimization } \\
\text { Program for } \\
\text { Radiological } \\
\text { Control }\end{array}$ & $\begin{array}{l}\text { Hanford Site } \\
\text { Radiological Control } \\
\text { Manual, HSRCM-1,Rev. } \\
\text { 2, Part 4, Articles 441, } \\
\text { 442, and 443, and Part 5, }\end{array}$ & $\begin{array}{l}\text { Describes radioactive waste minimization } \\
\text { program detailing required elements } \\
\text { including development of waste } \\
\text { minimization goals. Waste types include } \\
\text { solid and liquid LLW and MLLW. }\end{array}$ \\
\hline $\begin{array}{l}\text { Principal } \\
\text { Guidance to fully } \\
\text { implement } \\
\text { Pollution } \\
\text { Prevention } \\
\text { Program }\end{array}$ & $\begin{array}{l}\text { DOE 1996 Pollution } \\
\text { Prevention Program } \\
\text { Plan (DOE, 1996a) }\end{array}$ & $\begin{array}{l}\text { Provides contractors with specific steps } \\
\text { to meet DOE's pollution prevention } \\
\text { commitments. }\end{array}$ \\
\hline
\end{tabular}


DOE/RL-91-31, Rev. 4

This page intentionally left blank. 
DOE/RL-91-31, Rev. 4

APPENDIX C

SECRETARIAL MEMORANDUM: DEPARTMENT POLLUTION PREVENTION GOALS 
DOE/RL-91-31, Rev. 4

This page intentionally left blank. 


\title{
MEMORANDUM FOR HEADS OF DEPARTMENTAL ELEMENTS
}

\author{
FROM: $\quad$ HAZEL R. O'LEARY
}

SUBJECT: $\quad$ Departmental Pollution Prevention Goals

The Department of Energy pollution prevention strategy is to reduce the generation of all waste streams and thus minimize the impact of departmental operations on the environment. Preventing pollution also reduces risks to the health and safety of workers and the general public and saves scarce budget dollars. To demonstrate the Department's commitment to pollution prevention, we have set the following goals to be achieved by December 31, 1999, using calendar year 1993 as a baseline year.

For Routine Operations:

- Reduce by 50 percent the generation of radioactive waste.

- Reduce by 50 percent the generation of low-level mixed waste.

- Reduce by 50 percent the generation of hazardous waste.

- Reduce by 33 percent the generation of sanitary waste.

- Reduce by 50 percent total releases and off-site transfers for treatment and disposal of toxic chemicals.

For All Operations, Including Cleanup/Stabilization Activities:

- Recycle 33 percent of sanitary waste.

For Affirmative Procurement:

- Increase procurement of Environmental Protection Agency-designated, recycled products to 100 percent, except where they are not commercially available competitively at a reasonable price or do not meet performance standards.

Operations Offices will direct sites under their purview to set site-specific goals to assist in achieving the departmental goals. Progress toward meeting the departmental goals will be reported annually to me. It is the responsibility of each Federal and contractor manager to work diligently to meet these goals; to aggressively seek ways to reduce the amount of pollutants generated within the workplace; and to conserve, reuse, and recycle resources. 


\section{DOE/RL-91-31, Rev. 4}

This page intentionally left blank. 